\title{
Bioassay Studies for Testing Toxicity of Novel Insecticides against Helicoverpa armigera (H.)
}

\author{
Sashanka Sekhar Dash*, M. Lava Kumar Reddy, G. Sridevi and Bharathi N. Bhat \\ Professor Jayashankar Telangana State Agricultural University, Hyderabad-500030, \\ Telangana, India \\ *Corresponding author
}

K e y w o r d s
$\begin{aligned} & \text { H. armigera, } \\ & \text { chlorantraniliprole, } \\ & \text { spinetoram, } \\ & \text { indoxacarb }\end{aligned}$
Article Info
$\begin{aligned} & \text { Accepted: } \\ & \text { 20 December } 2019 \\ & \text { Available Online: } \\ & \text { 20 January } 2020\end{aligned}$

A B S T R A C T

Bioassay studies were conducted in the Department of Entomology, College of Agriculture, Rajendranagar, Hyderabad to determine the relative toxicity of selected novel insecticides viz., chlorfluazuron, chlorantraniliprole, spinetoram, indoxacarb, emamectin benzoate and spinosad against second instar larvae of H.armigera by topical application, residue method and surface diet method. The data on the toxicity of insecticides to $H$. armigera, clearly indicated that among the six insecticides tested against the second instar, irrespective of the method of application, spinetoram, indoxacarb and spinosad showed greater toxicity compared to chlorfluazuron, chlorantraniliprole and emamectin benzoate. While in the latter three insecticides, the toxicity to $H$. armigera was comparatively higher in topical application than other methods although in case of emamectin benzoate it was almost similar with surface diet method.

\section{Introduction}

Bioassay is defined as "the measurement of the potency of any stimulus which may be physical, chemical, biological, physiological or psychological etc. by means of the reactions which it produce in the living organism" (Finney, 1952).

Bioassay helps in ascertaining the potency and relative toxicity of different insecticides. The bioassay methods commonly employed to insect toxicity evaluations are topical application by Potter's tower, injection method, leaf dip, contact or residue film method etc. The $\mathrm{LC}_{50}$ values serve as a ready reckoner for the selection of insecticides to work out strategy for the management of insect pest under field conditions. Also, such baseline data would provide a record for detecting resistance level of the insect pests to various insecticides at different periods. The cotton bollworm $H$. armigera, continues to maintain a high pest status in India where 
huge crop losses up to 80 per cent were recorded. This being a polyphagous pest with high reproductive damage potential, its suppression has become inevitable over past decade due to development of resistance to almost all commonly used insecticides. Insecticide resistance in $H$. armigera in India was first recorded in 1987 (McCaffery et al., 1989) when widespread field control failures were reported by farmers growing cotton and pulse crops in the coastal cotton growing belt of Andhra Pradesh.

\section{Materials and Methods}

The present research work titled "Bioassay studies for testing toxicity of novel insecticides against Helicoverpa armigera (H.)" was carried out in the Department of Entomology, College of Agriculture, Rajendranagar, Hyderabad during the year 2018-19. The materials used for the study and methods adopted are given here under.

\section{Mass rearing of $\mathrm{H}$. armigera}

\section{Collection of eggs/larvae}

The eggs of $H$. armigera were obtained from NBAIR, Bangalore and from ICRISAT, Hyderabad whereas the larvae were collected in polythene bags containing fresh red gram leaves from Students' farm and College farm, College of Agriculture, Rajendranagar, Hyderabad and also from farmer's fields in Ranga Reddy district, Hyderabad.

\section{Rearing of H.armigera}

The eggs obtained from NBAIR, Bangalore and from ICRISAT, Hyderabad were kept separately in plastic jars. Upon hatching, the eggs were transferred to bigger petriplates containing modified semi-synthetic diet (Ahmad and McCaffery, 1991), the ingredients of which are given in Table 2.1.

\section{Preparation of insecticidal solution}

A total of six novel insecticides were used to carry out the bioassay studies. The details of the insecticides used in the study are furnished in Table 2.2.

Stock solution of one per cent of $100 \mathrm{ml}$ was prepared for each insecticide by dissolving their respective formulations in distilled water. The treatments were replicated thrice. Ten larvae of five days old ( $2^{\text {nd }}$ instar), were used for each replication. The concentrations used in the study are given in Table 2.3.

\section{Bioassay Procedure}

Topical application, residue film method and surface diet method (Paramasivam and Selvi, 2017) were followed to evaluate the toxicity of the test insecticides to the $2^{\text {nd }}$ instar larvae of $H$. armigera.

\section{Topical application method}

Ten larvae of test insect were kept in a petri dish. The toxicant solutions were applied topically on the dorsum of second instar larvae (five days old) using Potter's tower at $760 \mathrm{~mm}$ $\mathrm{Hg}$ column difference air pressure. One $\mathrm{ml}$ of each insecticidal formulation was used for spraying. The petriplates were allowed to dry under fan and fresh diet was given to the larvae after treatment in Petri dishes. The Petri dishes were covered with Whatman's filter paper to maintain humidity. Three replications of each treatment were maintained and mortality was recorded after 24 hours.

\section{Residue film method}

In a petri dish of $5 \mathrm{~cm}$ diameter $1 \mathrm{ml}$ solution of desired concentration of insecticides was sprayed with the help of Potter's spray tower and allowed to dry under an electric fan to get residue film. Desired concentration of each 
insecticides were made and in each concentration ten larvae were exposed to residue film. Each treatment was replicated thrice. The mortality was recorded after 24 hours.

\section{Surface diet method}

Three $\mathrm{ml}$ of the diet was pipetted into cell well trays and allowed to cool at room temperature for approximately 1 hour. For each test insecticide, serial dilutions of formulated material $(100 \mu \mathrm{l}$ aliquots) were pipetted onto the diet surface and allowed to dry for approximately 30 minutes. Second instar larvae were placed into a series of cell well trays that contained different concentrations of formulated insecticides. Each treatment was replicated thrice. Then mortality was recorded after 24 hours.

\section{Analysis of the data}

The corrected mortality was calculated by subjecting the observed mortality to Abbott's (1925) formula,

Test mortality (\%) - Control mortality (\%) Corrected mortality $(\%)=$
Dose mortality regressions $\left(\mathrm{LC}_{50}\right)$ were computed by probit analysis (Finney, 1971) using BIOSTAT 2006 Software.

\section{Results and Discussion}

The $\mathrm{LC}_{50}$ values for chlorfluazuron, chlorantraniliprole, spinetoram, indoxacarb, emamectin benzoate and spinosad against $H$. armigera were $0.0088,0.0057,0.0002$, $0.0002, \quad 0.0059$ and 0.0002 per cent, respectively by topical application; 0.0231, $0.0098,0.0002,0.0003,0.0090$ and 0.0001 percent, respectively by residue film method and $0.0127,0.0076,0.0001,0.0001,0.0060$ and 0.0003 per cent, respectively by surface diet method of bioassay. From this experimental data on the toxicity of insecticides to $H$. armigera, it was clearly evident that among the six insecticides tested against the second instar spinetoram, indoxacarb and spinosad showed greater toxicity by all the three methods of application compared to chlorfluazuron, chlorantraniliprole and emamectin benzoate. It was also revealed that the method of application in case of spinetoram, indoxacarb and spinosad, did not influence the toxicity of insecticides $\left(\mathrm{LC}_{50}\right.$ ranged between 0.0001$0.0003)$.

Table.1 Diet composition for $H$. Armigera

\begin{tabular}{|l|l|l|}
\hline Sl. No & Ingredients & Quantity \\
\hline 1 & Chickpea flour & $160 \mathrm{~g}$ \\
\hline 2 & Wheat germ & $60 \mathrm{~g}$ \\
\hline 3 & Sorbic acid & $1.7 \mathrm{~g}$ \\
\hline 4 & Dried yeast & $53 \mathrm{~g}$ \\
\hline 5 & L- Ascorbic acid & $5.3 \mathrm{~g}$ \\
\hline 6 & Methyl paraben & $3.3 \mathrm{~g}$ \\
\hline 7 & Agar- agar & $20 \mathrm{~g}$ \\
\hline 8 & Formaldehyde $10 \%$ & $14 \mathrm{ml}$ \\
\hline 9 & Antimould & $2 \mathrm{ml}$ \\
\hline 10 & Distilled water & $1200 \mathrm{ml}$ \\
\hline
\end{tabular}


Table.2 Details of insecticides tested for relative toxicity against $H$. armigera

\begin{tabular}{|c|c|c|c|c|}
\hline $\begin{array}{l}\text { Sl. } \\
\text { No }\end{array}$ & Common Name & $\begin{array}{l}\text { Trade } \\
\text { Name }\end{array}$ & Formulation & Source of Supply \\
\hline 1. & Chlorfluazuron & Atabron & $5.4 \mathrm{EC}$ & UPL Limited \\
\hline 2. & Chlorantraniliprole & Coragen & $18.5 \mathrm{SC}$ & $\begin{array}{l}\text { Dupont Chemicals (India) } \\
\text { Limited }\end{array}$ \\
\hline 3. & Spinetoram & Delegate & $11.7 \mathrm{SC}$ & Dow Agrosciences \\
\hline 4. & Indoxacarb & Isacarb & 14.5 SC & $\begin{array}{l}\text { Isagro Asia Agrochemicals } \\
\text { Pvt. Ltd. }\end{array}$ \\
\hline 5. & Emamactin benzoate & Reclaim & $5 \mathrm{SG}$ & Aegis Pvt. Ltd. \\
\hline 6. & Spinosad & Tracer & $45 \mathrm{SC}$ & Dow Agrosciences \\
\hline
\end{tabular}

Table.3 Concentration of insecticides used in bioassay studies against $H$. armigera

\begin{tabular}{|l|l|}
\hline & \multicolumn{1}{c|}{ TOPICAL APPLICATION } \\
\hline Insecticides & Concentration used \\
\hline Chlorfluazuron & $0.5,0.1,0.05 .0 .01,0.005,0.001,0.0005$ \\
\hline Cholrantraniliprole & $0.005,0.0001,0.00005,0.00001,0.000005,0.000001,0.0000005$ \\
\hline Spinetoram & $0.01,0.005,0.001,0.0005,0.0001,0.00005,0.00001$ \\
\hline Indoxacarb & $0.0007,0.0005,0.0003,0.0001,0.00007,0.00005$ \\
\hline Emamectin benzoate & $0.5,0.03,0.01,0.007,0.005,0.003,0.001$ \\
\hline Spinosad & $0.003,0.001,0.0007,0.0005,0.0003,0.0001,0.00007$ \\
\hline & RESIDUE FILM METHOD \\
\hline Insecticides & Concentration used \\
\hline Chlorfluazuron & $0.5,0.1,0.05 .0 .01,0.005,0.001,0.0005$ \\
\hline Cholrantraniliprole & $0.005,0.0001,0.00005,0.00001,0.000005,0.000001,0.0000005$ \\
\hline Spinetoram & $0.01,0.005,0.001,0.0005,0.0001,0.00005,0.00001$ \\
\hline Indoxacarb & $0.005,0.001,0.0007,0.0005,0.0003,0.0001,0.00007,0.00005$ \\
\hline Emamectin benzoate & $0.05,0.03,0.01,0.007,0.005,0.003,0.001$ \\
\hline Spinosad & $0.007,0.005,0.003,0.001,0.0007,0.0005,0.0003,0.0001,0.00007$ \\
\hline & \multicolumn{1}{|c|}{ SURFACE DIET METHOD } \\
\hline Insecticides & Concentration used \\
\hline Chlorfluazuron & $0.5,0.1,0.05 .0 .01,0.005,0.001,0.0005$ \\
\hline Cholrantraniliprole & $0.005,0.0001,0.00005,0.00001,0.000005,0.000001,0.0000005$ \\
\hline Spinetoram & $0.01,0.005,0.001,0.0005,0.0001,0.00005,0.00001$ \\
\hline Indoxacarb & $0.0007,0.0005,0.0003,0.0001,0.00007,0.00005$ \\
\hline Emamectin benzoate & $0.5,0.03,0.01,0.007,0.005,0.003,0.001$ \\
\hline Spinosad & $0.003,0.001,0.0007,0.0005,0.0003,0.0001,0.00007$ \\
\hline &
\end{tabular}


However in the remaining three insecticides viz. chlorfluazuron, chlorantraniliprole and emamectin benzoate, the toxicity to $H$. armigerawas comparatively higher in topical application than other methods although in case of emamectin benzoate it was almost similar with surface diet method $\left(\mathrm{LC}_{50^{-}}\right.$ 0.0059 and 0.0060 ).

From the above studies it can be concluded that there was less variation in the toxicity of insecticides between the different methods of application.

\section{References}

Abbott, W. S. 1925. A method of computing the effectiveness of an insecticide. Journal of Economic Entomology 18: 265-267.

Ahmad, M and McCaffery, A.R. 1991.
Elucidation of detoxification mechanisms involved in resistance to insecticides in the third instar larvae of a field-selected strain of Heilcoverpa armigera with the use of synergists. Pesticide Biochemistry and Physiology. 41: 41-52.

Finney, D.J. 1971. Probit Analysis. S. Chard and Co., New Delhi. Pp 333.

McCaffery, A.R., King, A.B.S., Walker, A.J and El-Nayir, H. 1989. Resistance to synthetic pyrethroids in the bollworm Heliothisarmigera from Andhra Pradesh, India. Pesticide Science. 27: 65-76.

Paramsivam, M and Selvi, C. 2017. Laboratory bioassay methods to access the insecticides toxicity against insect pests- A review. Journal of Entomology and Zoology studies. 5(3): 1441-1445.

\section{How to cite this article:}

Sashanka Sekhar Dash, M. Lava Kumar Reddy, G. Sridevi and Bharathi N. Bhat. 2020. Bioassay Studies for Testing Toxicity of Novel Insecticides against Helicoverpa armigera (H.). Int.J.Curr.Microbiol.App.Sci. 9(01): 2631-2635. doi: https://doi.org/10.20546/ijcmas.2020.901.298 